\title{
Pemasaran bagi Petualang sebagai Kegiatan Komunikasi Pemasaran
}

\author{
Ratih Tresnati
}

ABSTRACT

\begin{abstract}
Marketing for Adventurer aims adventurer as its consumers. Instead of revenue-based, adventurer consumer is based on lifestyle. Their hobbies are outdoor sports such as bungee jumping, rock climbing, off-road driving, wild-river canoeing, etc. Marketing for adventurer has specific strategic: (1) STP Strategy-market segmenting, market targeting, market positioning; (2) Customer Experience Strategy (CES) as the sequel of Experiential Marketing

(EM). EM focuses more on emotion touch and feelings.
\end{abstract}

Kata kunci: pemasarann bagi petualang, komunikasi pemasaran, strategi STP, CES.

\section{Pendahuluan}

Bila Anda jalan-jalan ke beberapa mal di Jakarta, jangan kaget kalau menemukan cukup banyak peralatan outdoor petualang dipajang di sejumlah gerai. Sekarang konsumen tidak akan kesulitan kalau mencari ransel, jaket, atau sepatu gunung. Bahkan, peralatan khusus untuk berburu atau menyelam pun ada di sana. Apakah ini pertanda orang Indonesia yang hobi berpetualang tambah banyak?

Jawabannya, belum tentu. Pasar petualang (adventurer) memang semakin menggeliat. Tapi, itu bukan berarti semua produk tersebut dibeli oleh petualang sejati. Pasal-nya, tidak sedikit konsumen membelinya gara-gara ingin tampil seperti seorang petualang. Maklum, pria mana sih yang tidak ingin kelihatan gagah dan berani?

Di Indonesia, meskipun pasar para petualang sejati sangat kecil, tetapi sebagai sasaran antara, kelompok petualang ini terbilang sangat potensial. Apalagi, kegiatan risk taker yang umumnya digemari para pria, ternyata menarik perhatian kaum hawa juga. Oleh karena itu, sebagian para pemasar di Indonesia menjadikan adventures lifestyle (gaya hidup petualang) sebagai positioning.

Melihat fenomena di mana populasi pasar petualang sejati dan nonpetualang (kelompok yang bukan petualang sejati), perusahaan harus menangkap peluang bisnis tersebut dengan mengubah pemasarannya ke "pemasaran bagi petualang" (marketing for adventurer). Dalam menggarap pasar petualang (adventurer market) tersebut, diperlukan trik khusus yang sesuai dengan jiwa dan perilaku konsumen akhir.

Bagaimana strategi pemasaran yang jitu untuk melakukan pemasaran bagi para petualang ( $m a r-$ keting for adventurer) tersebut. 


\section{2. "Segmenting", "Targeting", "Positioning", serta "Customer Experience"}

Guna mengubah pemasarannya ke pemasaran bagi petualang, perusahaan dapat melakukan dua hal yaitu: (1) Melakukan Segmenting, Targeting \& Positioning; (2) Dengan Strategi Pengalaman Pelanggan (Customer Experience Strategy).

\subsection{Segmenting, Targeting, Positioning}

Perusahaan yang memutuskan untuk beroperasi dalam pasar yang luas menyadari bahwa ia biasanya tidak dapat melayani seluruh pelanggan dalam pasar tersebut. Para pelanggan terlalu banyak dan berbeda-beda dalam persyaratan pembelian mereka. Daripada bersaing di semua segmen, perusahaan perlu mengidentifikasi segmen pasar yang dapat dilayani paling efektif.

Untuk memilih pasar dan melayani mereka dengan baik, banyak perusahaan menerapkan pemasaran sasaran (market targeting). Dalam pemasaran, sasaran penjual membedakan segmensegmen pasar utama, membidik satu atau dua segmen itu, dan mengembangkan produk dan program pemasaran yang dirancang khusus bagi setiap segmen. Daripada menghamburkan usaha pemasaran mereka, mereka dapat memusatkan perhatian pada pembeli yang paling mungkin dapat mereka puaskan ( Kotler, 2003).

Selanjutnya, Kotler (2003) mengatakan bahwa pemasaran sasaran mengharuskan pemasar melakukan tiga langkah utama, yaitu: (1) segmenting (segmentasi pasar), yaitu mengidentifikasi dan membentuk kelompok pembeli yang berbeda, yang mungkin meminta produk dan atau bauran pemasaran tersendiri; (2) targeting (penetapan pasar sasaran), yaitu memilih satu atau lebih segmen pasar untuk dimasuki; (3) positioning (penetapan posisi di pasar), yaitu membentuk dan mengomunikasikan manfaat utama yang membedakan produk dalam pasar.

Segmentasi pasar adalah memilah-milah pasar dari yang heterogin menjadi ho-mogen dalam aspek tertentu (Kotler, 2003; Kotler \& Amstrong, 2001).
Segmen pasar (market segment) terdiri dari kelompok besar yang dapat diidentifikasi dalam sebuah pasar. Perusahaan yang menerapkan pemasaran segmen menyadari bahwa pasar/ konsumen berbeda-beda dalam keinginan, daya beli, lokasi geografis, perilaku pembelian, dan kebiasaan pembelian mereka. Oleh karena itu, perusahaan berusaha untuk memilah-milah atau memisah-misahkan beberapa segmen yang luas yang membentuk pasar. Contoh, produsen tas Eiger mengidentifikasi tiga segmen pasar, yaitu segmen petualang sejati, segmen urban adventure, yaitu mereka yang senang melakukan travelling, segmen adventure lifestyle yaitu mereka yang menyukai gaya-gaya outdoor.

Dengan melakukan segmentasi pasar, perusahaan dapat menciptakan produk yang lebih selaras dan mengenakan harga yang pantas bagi pasar sasaran.

Setelah perusahaan mengidentifikasi peluang segmen pasarnya, ia harus mengevaluasi beragam segmen dan memutuskan berapa banyak segmen pasar dan yang mana yang akan dibidik. Dalam menetapkan pasar sasaran, perusahaan akan melakukan evaluasi segmen pasar dan pemilihan segmen pasar (Kotler, 2003; Kotler \& Amstrong, 2001).

Dalam mengevaluasi segmen pasar yang berbeda, perusahaan harus memperhatikan: (1) daya tarik segmen secara keseluruhan, artinya perusahaan harus menanyakan apakah suatu segmen potensial memiliki karakteristik yang secara umum membuatnya menarik, seperti ukuran, pertumbuhan, profitabilitas, skala ekonomis, risiko yang rendah, dan lain-lainnya; (2) tujuan dan sumber daya perusahaan, artinya perusahan harus mempertimbangkan apakah berinvestasi dalam segmen tersebut masuk akal dengan memperhatikan tujuan perusahaan dan sumber daya perusahaan.

Setelah mengevaluasi segmen-segmen yang berbeda, kemudian perusahaan harus memilih segmen mana dan berapa banyak jumlah segmen yang akan dilayani de-ngan baik. Dengan kata lain, perusahaan harus memutuskan segmen mana yang akan dijadikan "target market/pasara sasaran" (= 
kelompok konsumen yang dituju, yang akan dilayani dengan program pemasaran tertentu).

Dalam sebuah industri yang terkenal ketat persaingannya, sebuah perusahaan kecil dapat bersaing melawan pesaing-pesaingnya dengan cara "mendiferensiasikan" produk dan jasanya. Diferensiasi adalah tindakan merancang satu set perbedaan yang berarti untuk membedakan penawaran perusahaan dari penawaran pesaing (Kotler, 2003; Kotler \& Amstrong, 2001).

Untuk produk fisik, perusahaan dapat melakukan diferensiasi dalam aspek-aspek: produk keistimewaan, kinerja, kesesuaian, daya tahan, kemudahan, mudah diperbaiki, gaya, rancangan), pelayanan (kemudahan pesanan, pengiriman, pemasangan, pelatihan pelanggan, konsultasi pelanggan, pemeliharaan dan perbaikan, keramahan), personil (kemampuan, dapat dipercaya, dapat diandalkan, cepat tanggap, komunikasi), saluran jangkauan, keahlian, kinerja saluran) serta citra (lambang, media tertulis dan audio visual, suasana, acara-acara).

Sedangkan untuk jasa, perusahaan dapat melakukan diferensiasi dalam aspek: (1) people/ personil (kemampuan personl, kesopanan, kredibilitas, dapat diandalkan, cepat tanggap, komunikasi), (2) physical environment (lingkungan fisik), artinya perusahaan jasa dapat mengembangkan lingkungan fisik yang lebih atraktif. Contoh, atmosfir yang ditawarkan Bank Indonesia, yang sejuk, nyaman, asri, dan terkesan aristokrat, (3) process (proses), artinya perusahaan jasa dapat merancang penyampaian jasa yang superior. Contoh, home banking (perbankan melalui rumah) yang dibentuk oleh bank.

Tetapi, tidak semua diferensiasi merek berarti atau berharga bagi konsumen. Oleh karena itu, perusahaan harus berhati-hati memilih cara untuk mendiferensiasikan produknya dari pesaingpesaingnya.

Selanjutnya, perusahaan harus mengomunikasikan atau mempromosikan per-bedaanperbedaan yang telah dimunculkan, yang dapat sangat menarik bagi pasar sasarannya. Dengan kata lain, perusahaan ingin mengembangkan suatu strategi penentuan posisi (positioning) yang terfokus.

Penentuan posisi adalah tindakan merancang penawaran dan citra perusahaan sehingga menempati suatu posisi kompetitifyang berarti dan berbeda dalam benak pelanggan sasarannya (Kotler, 2003; Kotler \& Amstrong, 2001. Contoh, perusahaan tas Eiger mendiferensiasikan dan memosisikan produknya dengan dimensi adventurer lifestyle.Artinya, pemasar tidak menargetkan kelompok risk taker, tetapi hanya menggunakan dimensi lifestyle untuk membidik kelompok non risk taker atau kelompok follower.

Menurut Kotler (2003), dasar yang digunakan untuk melakukan segmentasi pasar konsumen, yaitu variabel geografis (wilayah, ukuran kota atau kota besar, provinsi), variabel demografis (usia, ukuran keluarga, siklus kehidupan keluarga, jenis kelamin, pendapatan, pekerjaan, pendidikan, agama, ras, kewarganegaraan), variabel psikografis (gaya hidup/lifestyle, personality, social class), variabel perilaku (kejadian, manfaat pro-duk, status pemakai, tingkat pemakaian produk, status kesetiaan, tahap kesiapan membeli, sikap terhadap produk).

Dalam kaitannya dengan pokok bahasan dalam makalah ini, yaitu Marketing for Adventurer, perusahaan melakukan segmentasi pasar dengan variabel psikografis (psychographics). Psychographics didefinisikan sebagai penelitian kuantitatif dari gaya kehidupan konsumen yang dapat digunakan untuk membantu dalam pembuatan keputusan pemasaran, seperti lifestyle, social class, personality (Mowen, 1999).

Pada dasarnya, semua masyarakat memiliki strata (kelas sosial). Strata tersebut kadangkadang berbentuk sistem kasta di mana anggota kasta yang berbeda dibesarkan dengan peran tertentu dan tidak dapat mengubah keanggotaan kasta mereka. Stratifikasi lebih sering ditemukan dalam bentuk kelas sosial.

Strata/kelas adalah pembagian masyarakat yang relatifhomogen dan permanen, yang tersusun secara hirarkis dan memiliki anggota dengan nilainilai, minat, dan perilaku yang serupa (Kotler, 2003; Kotler \& Amstrong, 2001). Pembagian kelas sosial di negara Barat: upper upper, upper middle, up- 
per lower, middle upper, middle middle, middle lower, lower upper, lower middle, lower lower.

Kelas sosial tidak hanya mencerminkan penghasilan, tetapi juga indikator lain, seperti pekerjaan, pendidikan, dan tempat tinggal. Kelas sosial berbeda dalam busana, cara berbicara, preferensi reaksi, dan banyak ciri-ciri lain, antara lain: (1) orang-orang dalam kelas sosial yang sama cenderung bertingkah laku lebih seragam daripada orang-orang dari dua kelas sosial yang berbeda; (2) orang-orang merasa menempati posisi yang inferior atau superior sehubungan dengan kelas sosial mereka; (3) kelas sosial sesorang ditandai oleh sekumpulan variabel - seperti : pekerjaan, penghasilan, kesejahteraan, pendidikan, dan pandangan terhadap nilai; (4) individu dapat pindah dari satu kelas sosial ke kelas sosial lainnya (dari kelas atas ke kelas bawah) sepanjang hidup mereka.

Kelas sosial menunjukkan preferensi produk dan merek yang berbeda dalam banyak hal, seperti dalam pakaian, perabot rumah tangga, kegiatan dalam waktu luang, dalam mobil. Kepribadian (personality) adalah pola khas perilaku, termasuk pikiran dan emosi, yang menandakan adaptasi masing-masing individu dengan situasi hidupnya sendiri (Kotler, 2003; Kotler \& Amstrong, 2001).

Sedangkan menurut Mowen (1999), kepribadian yaitu pola-pola khusus pada perilaku, termasuk pikiran-pikiran dan emosi-emosi, yang mencirikan adaptasi setiap individu terhadap situasi kehidupannya.

Sedangkan menurut Engel, Blackwell, Miniard (2001), kepribadian merupakan respons/tanggapan yang konsisten terhadap stimulus lingkungan. Kepribadian juga menyediakan pola khusus organisasi yang membuat individu unik dan berbeda dari individu lainnya.

Gaya hidup (life style) adalah pola hidup seseorang di dunia yang diekspresikan dalam aktivitas, minat, dan opininya (Kotler, 2003). Contoh, gaya hidup petualang.

Gaya hidup menggambarkan keseluruhan diri sesorang yang berinteraksi dengan lingkungannya. Gaya hidup adalah konsep yang lebih kontemporer, lebih komprehensif, dan lebih berguna daripada kepribadian. Ia juga dikatakan pola di mana orang hidup dan menghabiskan waktu serta uang. Gaya hidup juga dikatakan fungsi motivasi konsumen dan pembelajaran sebelumnya, sosial class, demografi, dan variabel lainnya. Jadi, Gaya hidup merupakan bagaimana seseorang hidup, bagaimana seseorang membelanjakan uangnya, serta bagaimna seseorang mengalokasikan waktu mereka, merupakan variabel yang abstrak (Mowen, 1999).

Hal senada juga dikemukakan David S. Simatupang (2005:29) yang mengatakan bahwa dalam meneropong pasar kaum petualang, lensa pemasaran tidak bias dilepaskan dari tren gaya hidup, dimana gaya hidup terdiri dari aktivitas (umumnya berhubungan dengan pekerjaan, kegiatan sosial, hiburan, dan komunitas), minat (terfokus pada area-area seperti rumah, rekreasi, fesyen, dan makanan), dan opini seseorang (terkait pada pekerjaan dan pencapaian pribadi seseorang).

Stanford Research Institute (SRI), yang terkenal dengan konsep VALS (Value and Lifestyle), tahun 1978, berhasil mengidentifikasi gaya hidup dan mengelompokannya ke dalam delapan kelompok besar, yaitu actualizer, achievers, fulfilled, experienncers, believers, makers, dan strugglers (Simatupang, 2005:29).

Jika kita merujuk tipe-tipe kelompok tersebut, maka segmen petualang tidak lain adalah kelompok experiencers.

\subsection{Pengalaman Pelanggan ("Customer Experience")}

Pemasaran, bagi petualang, dapat juga dilakukan dengan pengalaman pelanggan (customer experience). Seperti pendapat Bambang Bakti (2005:29) yang mengatakan bahwa "Banyak orang yang hanya sekadar ingin bergaya seperti petualang, tetapi dia belum tentu punya jiwa petualang.

Hal senada juga dikemukakan oleh David S. Simatupang (2005:31) bahwa dalam melakukan pemasaran bagi petualang, pendekatan yang paling cespleng adalah lewat customer experience (pengalaman pelanggan), di mana perusahaan memberikan pengalaman tak terlupakan kepada 
konsumen, misalnya, dengan menggelar extreme test-driver agar konsumen bisa melihat dan merasakan langsung ketangguhan mobil tersebut menghadapi medan yang sulit.

Pengalaman (experience) yang dimiliki seseorang merupakan buah dari adanya perubahan dalam perilakunya - dikenal sebagai pembelajaran (learning). Seperti yang dikemukakan oleh Kotler (2003), bahwa "pembelajaran meliputi perubahan dalam perilaku seseorang yang timbul dari pengalaman."

Selanjutnya, Kotler mengatakan bahwa "pembelajaran (learning) ini merupakan salah satu faktor yang mempengaruhi keputusan pembelian konsumen akhir (Kotler, 2003: 254). Sebagian besar perilaku manusia adalah hasil belajar. Ahli teori pembelajaran yakin bahwa pembelajaran dihasilkan melalui perpaduan kerja dorongan, stimulus, tanggapan, dan penguatan.

Dorongan (drive) adalah rangsangan internal yang kuat yang memotivasi tindakan. Misalkan, Salman memiliki dorongan aktualisasi diri. Dorongannya akan menjadi motifjika diarahkan menuju stimulus. Pengurang-dorongan tertentu, dalam kasus ini sebuah komputer. Tanggapan Salman terhadap ide membeli sebuah komputer diadaptasikan oleh petunjuk-petunjuk di sekelilingnya. Petunjuk (cues) adalah stimulus minor yang menentukan kapan, di mana, dan bagaimana tanggapan seseorang, misalnya, sokongan teman, melihat iklan di televisi, mendengar harga jual khusus komputer merupakan petunjuk (cues) yang mempengaruhi minat Salman dalam membeli sebuah komputer.

Pengalaman yang diperoleh seseorang itu dapat berdasarkan pengalaman pribadi ataupun pengalaman orang lain, contoh, Salman membeli komputer merek IBM, oleh karena temannya memiliki komputer merek IBM yang tetap terjaga kualitasnya walaupun telah berumur tahunan.

Para peneliti secara khusus membedakan dua jenis pembelajaran konsumen, yaitu pembelajaran kognitif dan pembelajaran perilaku (behavioral leraning) - (Mowen \& Minor, 2001:156).

Pembelajaran kognitif berfokus pada topiktopik yang relatif kompleks (seperti, bagaiman or- ang mempertahankan materi verbal, bagaimana mereka memperoleh wawasan, dan bagaimana mereka merencanakan). Kebanyakan ahli teori yang berorientasi kognitif memandang proses pembelajaran terjadi melalui pemrosesan informasi.

Menurut perspektif pembelajaran perilaku, perilaku merupakan sebuah tanggapan terhadap stimulus lingkungan. Pembelajaran perilaku, pada dasarnya merupakan sebuah proses di mana pengalaman dengan lingkungan yang mengarah pada perubahan perilaku yang relatif permanen atau potensial terhadap perubahan seperti itu.

Seperti semua proses pembelajaran, proses ini berasal dari pengalaman - bukan dari perubahan fisiologis yang disebabkan oleh pertumbuhan, kecelakaan, atau penyakit. Jadi, keadaan sementara seperti yang ditimbulkan oleh obat-obatan, tidak diklasifikasikan sebagai proses pembelajaran.

Menurut Mowen (1999) dan Mowen \& Minor (2001), ada tiga pendekatan utama dari proses pembelajaran perilaku, yaitu: (1) pengondisian klasik (clasiccal conditio-ning), di mana perilaku dipengaruhi oleh stimulus yang terjadi sebelum sampai pada perilaku tersebut dan mendapatkannya dalam keadaan berpenampilan refleks; (2) pengkondisian operant (operant conditioning), di mana perilaku dipengaruhi oleh konsekuensi perilaku; (3) pembelajaran meniru orang lain (social /vicarious learning), dimana orang-orang mengobservasi tindakan-tindakan orang lain atau meniru tindakan mereka.

Pendekatan classical conditioning, menggambarkan suatu mekanisme yang dengannya pembentukan sikap mengikuti suatu proses yang berbasis afektif, bukan proses yang berbasis kognitif (Engel, Blackwell \& Miniard: 1994), sedangkan menurut Mowen (1999); Mowen \& Minor (2001), classical conditioning adalah "perilaku dipengaruhi oleh stimulus yang terjadi sebelum perilaku dan membangkitkannya dengan cara yang munculnya sebagai refleks."

Menurut Pavlov, bapak classical conditioning memperlihatkan jenis pengalaman ini melalui prosedur sebagai berikut:

(1) Pertama, hubungan stimulus - respons yang sudah ada diseleksi. Contoh, Situasi muda- 
mudi yang sedang berpiknik menggunakan kapal pesiar mewah (sebagai "stimulus tak bersyarat"/STB) yang menghasilkan emosi yang menyenangkan (sebagai "respons tak bersyarat"/RTB).

(2) Kedua, stimulus baru (disebut "stimulus bersyarat"/SB). Contoh: Rokok Mr. Brown) kemudian disandingkan dengan makanan. Akhirnya SB-produk rokok Mr.Brown, akan menghasilkan "respons bersyarat"/RB yang sangat mirip dengan respons yang semula dihasilkan oleh STB yaitu emosi yang menyenangkan. perasaan) konsumen yang disentuh, sehingga mereka akan memberikan perhatian - pemahaman - tersimpan di memori jangka panjang (long term memory), tempat di mana informasi tersimpan lama secara permanen.

Kerangka dasar ini tersebut, biasanya akan diterapkan produk-produk yang tampak sama/ homogen (seperti rokok, bir, tissue, snack, celana jeans), mengingat mungkin mustahil bagi produsen untuk melakukan diferensiasi merek melalui penekanan atribut produk (seperti melalui kualitas, pembungkus, label dsb). Mereka akan melakukan diferensiasi melalui stimulus yang membangkitkan

\section{Gambar 2: "Classical Conditioning"}

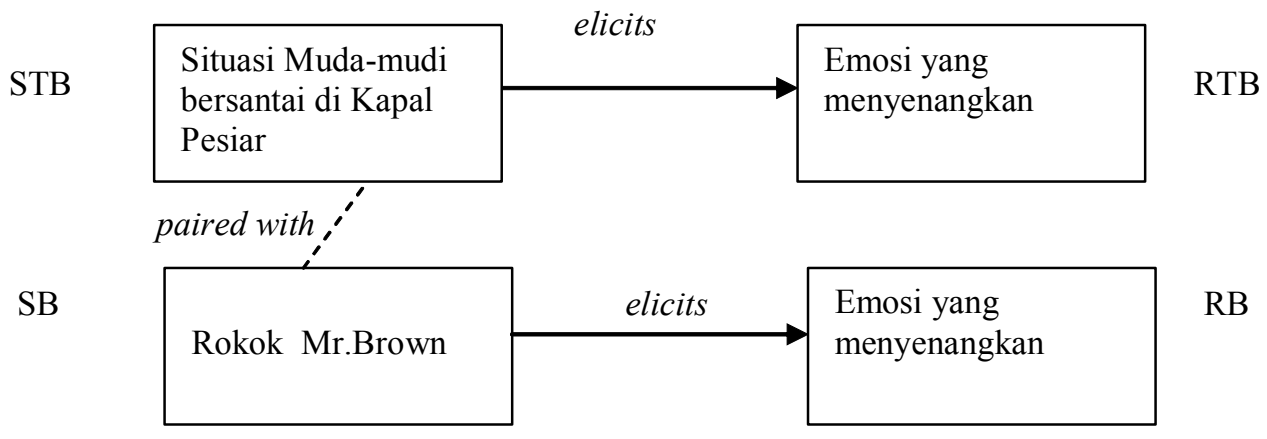

Sumber: John C.Mowen (1999)

Gambar di atas menyajikan kerangka classical conditioning yang mendasar di dalam suatu konteks produk. Contoh lain "iklan rokok Mr. Brown", di mana mula-mula ditayangkan suasana muda-mudi sedang berpesta di kapal pesiar mewah, ini merupakan "stimulus tak bersyarat" (STB). Suasana tersebut menghasilkan emosi yang menyenangkan, yang disebut "respons tak bersyarat" (RTB). Kemudian, rokok merek Mr. Brown yang merupakan Stimulus Bersyarat (SB) disandingkan dengan STB di atas, dengan harapan akan mendapatkan respons yang sama yaitu suasana yang menyenangkan, disebut "respons bersyarat" (RB).

Jadi, dalam gambar di atas, afeksi (emosi dan respons yang menyenangkan.

Pendekatan operant conditioning (pengkondisian peserta), pada dasarnya, merupakan tindakan yang terjadi dengan sendirinya dari suatu organisme di dalam lingkungan. Seperti, anjing berjalan, menggonggong, dan mendengus-dengus; burung merpati mematuk-matuk benda; bayi manusia merangkak, mengoceh tak henti-hentinya, serta suka memasukan benda-benda ke dalam mulutnya (Mowen:1999).

Lebih lanjut, ia mengatakan bahwa secara formal, operant conditioning adalah "proses di mana frekuensi kejadian perilaku dimodifikasi oleh akibat-akibat perilaku," seperti seseorang membeli 
snack merek "X", akibat-akibat perilaku tersebut akan mengubah kemungkinan terjadinya perilaku itu sekali lagi (terjadi pembelian ulang atau tidak terjadi). Tendensi individu-individu mengulangi perilaku seperti itu dipengaruhi oleh penguatan (reinforcement) yang berasal dari konsekuensikonsekuensi perilaku. Pengukuhan tersebut akan memperkuat tindakan-tindakan dan meningkatkan kemungkinan individu akan mengulangi perilaku tersebut. Dalam pemasaran, cara ini dikenal dengan promosi penjualan (sales promotion), di mana guna meningkatkan pembelian konsumen akhir produsen/penjual memberikan insentif berupa: sampel gratis, hadiah langsung, obral, diskon, voucher belanja atau menginap, kupon dan sebagainya.

Pendekatan Sosial (Social Learning /Observational/Vicarious Learning), dimana individuindividu mengamati tindakan orang lain dan meniru atau mencontoh tin-

dakan-tindakan. Strategi ini sering digunakan oleh para manajer pemasar guna merubah perilaku konsumennya, misalnya menggunakan public figure dalam iklan produk yang ditawarkannya, seperti Michael Jordan, Rudy Hartono, Mia Audiana, Susy Susanti, Ari Wibowo, Deasy Ratnasari dalam berbagai produk dengan harapan para public figur tersebut yang menjadi panutan para penggemarnya akan ditiru oleh para penggemarnya. Hal ini terjadi oleh karena, salah satu variabel yang mempengaruhi perilaku pembelian konsumen akhir adalah small reference group ( SRG). Seperti kita ketahui bahwa dalam masyarakat terdapat banyak kelompok konsumen seperti: kelompok olah ragawan, kelompok artis, kelompok ulama, kelompok pebisnis, kelompok ibu rumah tangga. Di dalam SRG tersebut terdapat opinion leader-nya (= seseorang yang diyakini mampu mempengaruhi orang lain).Yang menjadi opinion leader adalah mereka yang berprestasi di bidangnya. Biasanya, opinion leader ini akan menjadi panutan para pengikutnya, dan para pengikutnya akan meniru hal-hal yang dilakukan opinion leader tersebut. Pemasar tentu akan memanfaatkan opinion leader untuk menjadi bintang iklan produknya, dengan harapan perilaku opinion leader ditiru oleh banyak orang.

Dari uraian di atas, tampak bahwa ketiga pendekatan di atas (classical conditioning, operant conditioning, social learning) merupakan pendekatan yang berbasis kepada pengalaman pelanggan. Bila dicermati dengan baik, ketiga pendekatan di atas berbasis kepada afeksi (emosi dan perasaan) konsumen.

Pembelajaran perilaku (yang pada dasarnya merupakan sebuah proses di mana pengalaman dengan lingkungan yang mengarah pada perubahan perilaku yang relatif permanen atau potensial terhadap perubahan seperti itu) dewasa ini secara khusus di-expose untuk menjadikan mereka loyal sehingga perusahaan dapat memenangkan persaingan - strategi ini dikenal dengan cusomer experential strategy (CES).

$C E S$ itu merupakan sekuel /lanjutan dari experiential marketing (EM). Jadi, teori dasar CES ada di EM. EM, pada dasarnya, merupakan strategi perusahaan untuk membuat pelanggannya bisa lebih loyal dengan cara membangkitkan perasaan dan emosi pelanggan.

Bila emosi dan perasaan konsumen disentuh, akan menyebabkan ia merubah sikap dari tidak membeli menjadi membeli. Jadi, emosi dan perasaan berperan kuat pada setiap pelanggan ketika memutuskan untuk memilih merek suatu produk. Oleh karena itu, Bernd Schmitt menyarankan agar pemasar menciptakan experience/adventure, tidak hanya mengandalkan fitur (features) dan manfaat produk semata.

Mengapa hal-hal yang bersifat emosional itu penting bagi seorang pemasar? Karena, pada dasarnya, manusia itu merupakan makhluk yang terlahir telah dibekali dengan anggota badan yang sempurna, panca indra, akal, serta emosi dan perasaan, sehingga dikatakan bahwa manusia itu merupakan makhluk yang "emosional".

Langkah yang dapat dilakukan oleh perusahaan agar perusahaan dapat memiliki CES yang unik dan berbeda, yaitu dengan melakukan analisis terlebih dahulu terhadap kebutuhan pelanggan, atau dengan perkataan lain, perusahaan melakukan riset guna membuat CES yang unik dan berbeda. 
Dalam menjalankan CES "keunikan dan diferensiasi " tetap menjadi sesuatu yang penting, suatu pembeda/diferensiasi yang penting dan berarti bagi konsumen. Bila CES tidak memunculkan keunikan dan diferensiasi dibandingkan pesaing-pesaing perusahaan, maka CES akan menjadi strategi generik yang sama dengan CES pesaing. Contoh, perusahaan tas Eiger mendiferensiasikan produknya dengan dimensi adventurer lifestyle.

\section{Pemasaran bagi Petualang}

Pemasaran adalah suatu proses sosial dan manajerial di mana individu dan kelompok mendapatkan apa yang mereka butuhkan dan inginkan melalui penciptaan, penawaran, dan pertukaran (Kotler, 2003:9; Kotler \& Amtrong, 2001). Jadi, pemasaran merupakan kegiatan produsen untuk memuaskan needs \& wants konsumennya melalui pertukaran. Pertukaran merupakan inti dari pemasaran. Contoh, pertukaran antara produsen tas Eiger dengan para petualang dan nonpetualang.

Dalam rangka memuaskan kebutuhan dan keinginan konsumennya, produsen menggunakan bauran pemasaran yang terdiri dari produk, harga, tempat, serta promosi. Dengan menggunakan bauran pemasaran tersebut, produsen mencoba untuk mengomunikasikan produk/jasa yang dihasilkannya dengan pasar sasarannya.

Yang dimaksud dengan komunikasi pemasaran adalah aktivitas pemasaran yang berusaha menyebarkan informasi, memengaruhi/membujuk, dan/atau mengingatkan pasar sasaran atas perusahaan dan produknya agar bersedia menerima, membeli, dan loyal pada produk yang ditawarkan perusahaan yang bersangkutan (Kotler, 2003)

Petualang (adventurer) adalah kata-kata yang sangat disukai konsumen di Indonesia sebagai predikat gaya hidup. Konotasinya sangat beragam, bisa macho, keren dan pendobrak kemapanan.

Sedangkan marketing for adventurer adalah pemasaran yang membidik pasar/konsumen petualang, artinya perusahaan menargetkan pasar kepada pelanggan atau konsumen yang petualang.
Definisi petualang di sini bukan karena revenue based (basis pendapatan) konsumen, tetapi lebih kepada lifestyle (gaya hidup) atau hobi, seperti arung jeram, bungee jumping, rock climbing, offroad dan sebagainya (Bhakti, 2005: 32).

Jadi, dengan kegiatan marketing for edventurer tersebut, pemasar berusaha untuk berkomunikasi dengan para petualang sejati maupun petualang yang tidak sebenarnya (nonpetualang) yang mengasosiasikan diri mereka sebagai petualang, dengan menawarkan produkproduk yang menonjolkan berbagai atribut para petualang, seperti jaket, topi, kaos, pantalon, kemeja, motor besar, dan sebagainya.

\section{Pelaksanaan "Marketing for Adventurer" di Indonesia}

Diperkirakan, di Indonesia jumlah petualang sejati sangat kecil. Karena itu, para petualang ini termasuk kelompok niche market (pasar relung/ celah pasar). Konsekuensinya, tidak banyak pemasar yang memfokuskan diri untuk memanajeri pasar itu. Walaupun kelompok petualang sejati sangat kecil, tetapi sebagai sasaran antara, kelompok ini terbilang sangat potensial. Apalagi, kegiatan risk taker yang umumnya digemari para pria, ternyata menarik perhatian kaum hawa juga.

Berbagai perusahaan di Indonesia telah memasarkan produknya dengan pendekatan marketing for adventurer, antara lain perusahaan multi produk, PT Eigerindo Multi product Industry tersebut tidak sekadar hanya menawarkan produk, tetapi juga menawarkan pengalaman petualang. Guna menciptakan pengalaman tersebut, perusahaan itu sejak awal selalu menggunakan tema-tema petualangan dalam setiap kegiatan komunikasinya. Eiger sendiri punya tim ahli yang tergabung dalam Eiger Adventure Service Team (EAST). Tim tersebut terdiri dari beberapa pakar di bidang masing-masing seperti mountaineering climbing, para gliding dan mountain hiking. Peluncuran produk baru pun menggunakan adventure event sekaligus mengujicobakan produknya dengan kegiatan petualangan. Dengan begitu, asosiasi konsumen terhadap Eiger sangat ke aspek adventure. Sehingga dengan 
menggunakan merek Eiger, mereka seolah-olah menjadi petualang.

Tidak hanya berhenti dipersepsi, Eiger juga membentuk komunitas EAC (Eiger Adventure $C l u b$ ) yang beranggotakan para pelanggan setianya dan kerap melakukan berbagai petualangan. Kegiatan tersebut sengaja dirancang untuk mengikat konsumennya dalam bentuk pengalaman nyata, imbasnya merembet ke konsumen lain yang mengasosiasikan diri sebagai petualang. "Komunikasi kami lakukan lewat EAC yang merupakan kumpulan pelanggan setia kami. Selain itu, kami membuat Eiger Adventure News. Semua anggota EAC mendapatkan news ini, sebagai media komunikasi antara perusahaan dengan pelanggan. Juga kepada kelompok pecinta alam kampus di seluruh Indonesia. Jadi, salah satu cara kami adalah membentuk komunitas," katanya. "Dengan kegiatan adventure yang dirancang Eiger, konsumen merasakan adanya jalinan hubungan emosional dengan merek, misalnya Eiger menyediakan sepatu yang diperuntukkan untuk alam terbuka. Maka kami melakukan kegiatan itu. Selain itu, kami juga memberikan kursus bagaimana mendaki gunung yang aman. Dengan demikian, mereka tidak hanya sekedar memakai saja."

Eiger membidik tiga market terbesar, yaitu : (1) tecnical market, yaitu kelompok konsumen yang melakukan kegiatan petualangan; (2) travelling market, yaitu kelompok konsumen yang cenderung bepergian keluar kota baik jalan-jalan maupun melakukan business trip; (3) lifestyle market, yaitu orang-orang yang menggunakan Eiger untuk kegiatan sehari-hari dan ingin tampil dengan gaya petualang.

Produk yang diluncurkan tahun 1990 sudah memantapkan diri dengan image sebagai the real adventure. Keberhasilan merek Eiger itu sendiri dikarenakan konsumen sudah menganggap adventure merupakan bagian dari gaya hidup. Maka, segmen lifestyle pasarnya cenderung lebih besar dibandingkan dengan yang lain. Mereka bangga menggunakan merek Eiger karena related dengan para petualang dan itu dijadikan lifestyle oleh mereka. Saat ini Eiger juga memberikan experi- ence di setiap contact point dengan pelanggan. Di Bandung, misalnya, toko mereka memiliki sarana petualangan seperti tebing buatan yang bisa dijajal langsung oleh pengunjung. "Jadi, saat memasuki ke lingkungan toko, kami mencoba menciptakan rangkaian experience kepada pelanggan. Dengan cara seperti itu, ditambah dengan berbagai kegiatan gathering, mountain jaungle course dan aktivitasaktivitas petualangan lainnya, pelanggan merasa bangga jika memakai produk Eiger. Kebanggaan seperti itulah yang menjadikan mereka jadi konsumen Eiger" (Handi Irawan, 2006:32).

Tissot, sebuah merek jam terkenal asal Swiss, dikenal sebagai salah satu produk adventure. Padahal, segmen yang dituju tidak hanya anak muda, tetapi juga dewasa dari kelas sosial menengah ke atas.

TV 7, sebuah station TV di Indonesia, membuat produk (program) bertajuk "Jejak Petualang" (JP) yang bukan semata-mata ditujukan kepada para petualang, tetapi juga mencoba membidik keluarga (remaja, dewasa, dan orang tua), hal ini diperlihatkan dengan pencapaian rating 2,1 bagi program JP tersebut serta penayangan program tersebut pada prime time (jam $19.00 \mathrm{wib}$ ).

\section{Analisis Pemasaran bagi Petualang}

Dewasa ini, di masyarakat Indonesia, ada fenomena di mana muncul kelompok petualang sebagai kelompok risk taker. Walaupun jumlahnya kecil, namun kegiatan yang mereka lakukan telah mampu menarik perhatian "kelompok yang bukan petualang".

Perilaku konsumen beberapa produk (misalnya dalam membeli mobil) telah bergeser. Dari semula mereka lebih mementingkan fungsi dari produk tersebut, kini menjadi lebih mengutamakan gaya hidup. Dengan semakin berkembangnya lingkungan pemasaran, keinginan pelanggan semakin tidak terbatas; mereka menginginkan sesuatu yang lebih baru, praktis, dan menarik. Perubahan yang terjadi di lingkungan pemasaran tersebut, di mana jumlah petualang sejati dan nonpetualang semakin besar jumlahnya, maka hal ini merupakan peluang bisnis bagi para produsen. Peluang tersebut dapat dimanfaatkan oleh 
produsen "pemasaran bagi petualang" yang pada dasarnya merupakan kegiatan komunikasi pemasaran produsen dengan pelanggannya.

Guna mewujudkan hal tersebut, perusahaan dapat melakukan: (1) strategi segmenting, targeting, positioning (STP) dengan dasar yang digunakan adalah variabel psikografis terutama gaya hidup) yang pada dasarnya merupakan variabel abstrak; (2) pengalaman pelanggan (customer experience).

Seperti telah dibahas panjang lebar di atas, kedua strategi tersebut sangat ampuh untuk memuaskan pelanggan, dan pada akhirnya mereka akan loyal terhadap merek produk perusahaan. Namun, untuk melakukan kedua strategi tersebut bukanlah hal yang mudah, khususnya di Indonesia. Perusahaan harus melakukan riset untuk mengamati perilaku pelanggan, melakukan analisis terhadap kebutuhan pelanggan terlebih dahulu, karena fokus kepada pelanggan merupakan dasar bagi kedua strategi di atas.

Umumnya perusahaan-perusahaan di Indonesia, terutama perusahaan UMKM (Usaha Menengah Kecil dan Mikro) masih belum menganggap perlu untuk melakukan riset pemasaran untuk kemajuan perusahaan mereka. Mereka masih mengalami kesulitan untuk melakukan riset pemasaran, mengingat keterbatasan pengetahuan dan modal.

Oleh karena itu, tidak ada jalan lain selain pemerintah harus menyosialisasikan pentingnya melakukan riset. Disamping itu, perguruan tinggi harus menjadi motor penggerak dan membantu UMKM dalam memahami pentingnya riset pemasaran, karena menjadi sebuah keharusan sebelum menjalankan strategi STP dan Customer Experience tersebut.

\section{Kesimpulan}

Dalam rangka membidik para petualang dan nonpetualang, perusahaan harus mampu berkomunikasi dengan pelanggannya, yaitu dengan mengubah pemasarannya ke pemasaran bagi petualang (marketing for adventurer). Adapun strategi pemasaran yang jitu untuk melakukan hal tersebut, yaitu dengan melakukan:
(1) strategi STP, yaitu segmenting pasar: mengidentifikasi dan membentuk kelompok pembeli yang berbeda, yang mungkin meminta produk dan/atau bauran pemasaran tersendiri; targeting pasar sasaran: memilih satu atau lebih segmen pasar untuk dimasuki; positioning posisi di pasar: membentuk dan mengomunikasikan manfaat utama yang membedakan produk dalam pasar; (2) strategi pengalaman pelanggan (customer experience strategy/ CES), yang pada dasarnya merupakan sekuel dari Experiential Marketing (EM). Teori dasar CES merupakan strategi perusahaan untuk membuat pelang-gannya bisa lebih loyal dengan cara membangkitkan perasaan dan emosi pelanggan.

\section{Daftar Pustaka}

Bakti, Bambang. 2005. "Kuncinya Tahu Passion Needs Mereka." Majalah Marketing, No.06/ V/ Juni/2005, halaman 32.

Engel, Engel,F., Roger D. Blackwell, Paul W. Miniard 1994. Perilaku Konsumen. Alih bahasa FX Budiyanto. Jakarta: Binarupa Aksara.

Irawan, Handi. 2006. Pekerjaan Scmitt Belum Selesai. Majalah Marketing, No.03/ VI/ Maret/2006, halaman 34.

Kotler, Philip, Amstrong. Gary, 2001. Principles Of Marketing, Ninth Edition. New Jersey: Prentice Hall, Inc.

Kotler, Philip.2003. Marketing Management: Analysis, Planning, Implementation and Control. Millenium Edition. USA: Prentice Hall Inc.

Mowen, C., John.1999. Consumer Behavior. Fourth Edition.Oklahoma: Prentice Hall International edition Oklahoma University.

Mowen, C.John, Michael Minor 2001. Perilaku Konsumen. Alih Bahasa Dwi Kartini Yahya. Jakarta: Erlangga.

Simatupang, David. 2005. "Pendekatan yang paling Cespleng adalah lewat Experiential Marketing". Majalah Marketing, No.06/ V/Juni/2005, halaman 31. 
Terakreditasi Dirjen Dikti SK No. 56/DIKTI/Kep/2005

2006. "Menyihir Dengan Brand Experience." Majalah Marketing, No.03/VI/Maret/ 2006, halaman 38 . 
